\title{
Beauty class and the practice of beautification among lower middle-class young women
}

\author{
Ninik Tri Ambarwati \\ Graduate Student of Media and Cultural Studies Program. The Graduate School of \\ Universitas Gadjah Mada, Teknika Utara Street Yogyakarta. 55281 \\ e-mail: triambarwati884@gmail.com
}

\begin{abstract}
Beauty class is a place for a woman to share experiences in applying makeup. The participants in beauty class obtain tips and trick or some specific ways of applying makeup. The participants in this class can directly practice the knowledge on how to apply makeup on their faces. The beauty class phenomenon has existed in Indonesia since 2000. Beauty class becomes a trend which attracts young women. Beauty class becomes a place where ideal beauty is constructed, for instance, white skin for body and face, thick eyebrows, long eyelashes, pointed nose, oval face, and pink lips. This research aims to see the consumption practice by lower-class young women at beauty class in Yogyakarta. This research uses ethnography method by attending and observing the beauty class and having an interview with two active participants in the beauty class. This research shows that 1). Makeup has become a part of the everyday lifestyle of young women. 2). Beautification practice is determined by some beauty standards identified by the other party, in this case, cosmetics industry, and beauty blogger. 3). Beauty class opens an access for lower-middleclass women to use a wide range of cosmetics palette and tools that beyond what they can afford.
\end{abstract}

\section{Keywords}

beauty class, consumption, makeup, middle class, woman

\section{Introduction}

Citation: Ambarwati, N. T. (2018). Beauty class and the practice of beautification among lower middle-class young women. In M. Amini, M. Yusuf, \& V. I. Yulianto. (Eds.), UGM Digital Press Social Sciences and Humanities: Vol. 1. Proceeding of the 2nd International Conference on South East Asia Studies, (pp. 87-94).

Published: October, 2018
Beauty cannot be separated from woman body. In fact, what is defined as beautiful is the result of social construction? Social constructions of beauty eventually come to be accepted as the "normal standard" or as the natural standard (Kenny, et al, 2017, p. 293). Beauty becomes reality standard that is formed through social construction. Berger defines reality as a social construction. In other words, he says that reality is formed not by material-physics power formation, but a developed ideological power. It is even manipulated collectively through everyday social interaction (Faruk, 2000).

Every culture has its own beauty construction. In Short, it is Asian beauty according to the white imagination. In Asia for instance, white skin becomes a beauty standard. (Rondilla, 2009, p. 64). Specifically, In Indonesia, white skin and white face, sharp nose, thick eyebrows, flicked eyelashes, flushed cheeks, and red lips have become the

This work is licensed under the Creative Commons Attribution 4.0 International License. 
dominant construction of a woman to be considered as a pretty woman.

Those women images then make beauty becomes a myth. The beauty myths are used as a guide to be pretty. A myth creates a distinctive worldview and apparently inviolable because they "already exists by nature" or a gift from God (Barker, 2014, p. 184). Something is considered as correct by labeling certain myths. Myth has a duty to give eternal justification in the particular historical contingency (Barker, 2014, p. 184). Beauty is seen as something valuable and should be owned. Therefore, it is not uncommon to see the women who are so obsessed to be a beauty. They flock to go to the store to buy cosmetics to meet the word "pretty".

Cosmetics is a set of materials that are usually applied to decorate the whole face, lips, eyebrows, eyelashes, nose, cheeks, hair, and nails. According to the FDA, Food and Rugs Administration United States, cosmetics are defined as articles intended to be applied to the human body for cleansing, beautifying, promoting attractiveness, or altering the appearance without affecting the body's structure or its functions (www.fda.gov, 2016). In other words, cosmetics are used to clean, beautify, raising someone's appeal, or change the appearance without affecting the body's structure and function. Tilaar cosmetic explains that Cosmetics are something that can be applied or sprinkled. They are elements that can raise the strength of the body (Tilaar, 1999, p. 173).

To meet beauty myth, cosmetics are then regarded as something that must be possessed and consumed by women. A woman's face would be considered more beautiful using cosmetics. Therefore, It has an impact on the consumption of cosmetics. Buying cosmetics has become a new routine in women's lives. Buying cosmetics is believed can put them one step further to be a beautiful woman.

Cosmetics advertisement makes an ideal image of a beautiful face produced and continuously reproduced. The image of the ideal face which is buried for so long and the desire to meet the word "pretty" has finally got its satisfaction from the cosmetics. Eyes which have a function to see begin attached with colorful eyeshadow, eyelashes are attached with waterproof mascara and even fake eyelashes to make them look thick and long all day. The lips whose function to speak are attached with colorful lipsticks. All of these are intended to meet the criteria of ideal pretty. Thus, cosmetics became women's need in order to fulfill the desire to have a good body and pretty face.

Beauty Myth makes women feel "in need" of cosmetic. In other words, the desire to be pretty and the need to dress up beautifully is not something given to women (Budiman, 2000, p. 47). Woman beauty body procedure applied to woman's body through the practice of cosmetology and cosmetics, and how is the woman's body when it is called as a feminine (Budiman, 2000, p. 47).

The consumption of cosmetics is in line with the report of the data from the Ministry of Industry; cosmetic sales in Indonesia grew by double digits annually. In 2016, the sales reached IDR9,760,000,000,000; it is $14 \%$ higher than the previous year. This year the Ministry of Industry predicts that the sales will rise by $15 \%$ to IDR11,220,000,000,000 (kemenperin.go.id, 2017). The growth in the volume of cosmetic trade is driven by the demand from the middle class. Global Business Indonesia Guide explains Cosmetic sales volume growth in the country has been underpinned by increased demand: particularly from middle-class consumers (www.gbgindonesia.com, 2016).

The research shows that in Indonesia, the consumption of decorative cosmetics like eye makeup and lipsticks has a high percentage which is until $74 \%$. (marketeers.com). The increase in the cosmetics consumption is driven by the demand to fulfill the ideal beauty standard. The hat is by using decorative products. Beside cosmetics consumption, beauty class also cannot be separated from the demand of lower-middle-class women to fulfill the beautiful image. The beauty class opens an opportunity for the lower middle-class women to try various cosmetics.

Nowadays there are beauty classes from some particular cosmetic products. Beauty class is a place to share experiences on how to apply makeup. Participants in beauty classes usually get tips and tricks or the special way in applying makeup. The participants of this class can directly practice the knowledge of how to apply makeup to their face. Beauty class becomes a trend that attracts young women. Beauty class is being an ideal space where beauty is constructed.

The women do not only attend beauty class, they are generally also watching beauty blogger on YouTube. Beauty blogger is the blog owner who applies the cosmetics, make a review of certain beauty products, and sometimes promote the cosmetics they use on youtube. Beauty blogger becomes a place to learn the way to apply makeup in the right way for those who want to fulfill the beautiful image. The technology and the ease to access internet helps them to use make-up rightly.

Naomi Wolf in The Beauty Myth (2002) considers that the efforts of the beauty industry have been a part of patriarchy system that controls women's freedom. Instead of giving a direct attack, patriarchy in the beauty industry affects women with the myth of beauty. As explained by Naomi Wolf, Beauty Myth as a feminization tool makes them feel unsatisfied with their body, feel afraid that they cannot satisfy the 
men, even hate themselves (Wolf, 2002, p. 10). In capitalist's point of view, beauty can be a strategic area that can be used as a commodity. Therefore, do not be surprised if this beauty myth is continuously reproduced to perpetuate the capitalism and patriarchy system. This theory became a reference in this study to explain: first, how dressing up became a part of the lifestyle for young women. Second, beautification practices are determined by the standards of beauty defined by outsiders outside the women, such as cosmetic and beauty bloggers. The third is, beauty class opens access for the lower middle class to use a wide range of cosmetics palettes and tools that are beyond what they can afford. This study aims to look at the consumption practice by the under middle-class women in beauty class in Yogyakarta.

\section{Methods}

This research was conducted with the ethnographic method by attending and observing the beauty classes. The researcher the interviewed two people who actively participate in the beauty class. These people at least more than four times they come in the beauty class. This method is performed to determine how the women consume the cosmetics in beauty classes.

\section{Results and Discussions}

\subsection{Cosmetics and Women}

Women and beauty are two things that cannot be separated. Talking about women's face will also talk about their beauty. Therefore, the demand to always look beautiful will always follow the women wherever they go, wherever they are, and what age they are at. The use of cosmetic is one of the actions to realize the beauty of women. Even applying cosmetics to the face is considered able to increase the confidence of women. In other words, makeup is used differently in different situations because It makes women feel more self-confident (Britton, 2012, p. 6). Using cosmetics can increase the confidence. Tisa and her daughter Said.

\footnotetext{
"I started using makeup from 2013, I could not have missed moisturizer, powder, eyeliner and lipstick. Makeup has become my daily routine before I go to college. I feel like there's something wrong with my face and I feel less confident if I don't put makeup on my face." Putri said in the interview.
}

"Well, I started using makeup recently in 2016. I must use a facial moisturizer, eyebrow pencil, and lipstick because my lips are a bit pale. So I never feel confident without lipstick." Tisa Said.

The specialty of decorative cosmetics (makeup) is that this kind of cosmetic is intended solely to change the appearance, that is to look more beautiful and to cover some spots in the face (Tranggono and Latifah, 2007, p. 90). They tend to cover things that reduce their beauty in the face, lips, eyebrows, and eyelashes. They need makeup which can hide their flaws. The use of cosmetics for psychological reasons, that is by using cosmetics, someone wants to hide the flaws in the face, she wants to look more beautiful and more attractive. (Latifah and Tranggono, 2007, p. 90). An ideal image of a beautiful face has eroded self-confidence of women. The beauty myth serves as a guide to look pretty "real".

"I love applying red lipsticks best. My lipstick should be red. I have a variety of lipsticks brands like makeover, Wardah, NYX and Emina. I just feel more beautiful and sexy every time I wear colored lipsticks. I can get attention from many people, I can be like in the center of attention. Moreover, When I had crushed on a guy, I put makeup like every time" Putri said.

Applying cosmetics on the face is always related to the beauty of women in general, many women agree with this opinion. The face, in the end, has been a sign of submission of women to the cultural construction and the male gaze. Red Lipsticks is often associated with sensual color. Many women think they will look beautiful and attractive in this color. Red lipsticks to attract the male gaze and put the male as the audience. As stated Laura Mulvey (1975) in her essay, She explains how the image of women is presented as a perspective view of male view and patriarchal ideology, women are watched and men are the audience. He said; 
"In a world ordered by sexual imbalance, pleasure in looking has been split between active male and passive female. The Determining male gaze projects its phantasy on to the female figure of which is styled accordingly"

"Woman is more attractive with makeup than without. The woman themselves felt that they were physically attractive with makeup; Often overestimated their attractive with the makeup, while underestimating their attractiveness without makeup (Cash in Briton, 2012, p. 6).

Therefore, the cosmetic has functions to cleanse, beautify, raising someone's appeal, or change the facial appearance. As Said by Naomi Wolf, Beauty Myth as a feminization tool makes them feel unsatisfied with their body, feel afraid that they cannot satisfy the men, even hate themselves (Wolf, 2002, p. 10). The ideal image of a beautiful face which is buried for so long and the desire to be beautiful has gotten its satisfaction through the application of cosmetics on the face. Women feel obliged to put makeup on because body image is strongly influenced by the views of men. It can be said that it is a form of social control that affects the way the women see themselves and how they are seen by others. Women's hope for their physical has added the value of beauty itself so that women become more fragile and sensitive to their appearance (Melliana, 2006, p. 17). Women depend on the attractiveness of their physical appearance for their self-esteem. Assessment of the appeal of the physical appearance of women and men is caused by the physical stereotypes in society. Stereotype offers the perspective that a category is given inherent characteristics and universal so, this characteristic represents what is inside a person. (at present) and how it is in the future (Barker, 2014, p. 271). Then those who are physically considered not having an ideal face, such as those who have pale or black lips, thin eyebrows, and dark face are considered unattractive by the people. Basically, women are more rated and praised for their physical appearance than their inner beauty. When these stereotypes become dominant in the society, The women will be continuously trapped in the myth of beauty.

Cosmetics ads have constructed the image of women with "ideal beauty". The ideal figure would encourage expectations to have a dream face. The women make the model displayed in cosmetics advertisement as a standard of beauty. Cosmetics ads are like the bridge between reality and what is considered as ideal. The advertisement has been referred to as the beauty myth that affects the television viewers to receive commercial messages as the truth than just a beauty construction (Melliana, 2006, p. 60 ). The notion that women who have pretty face will get a more positive response from the community and be the center of attention is one reason that causes most beautiful women try to meet the beauty criteria. A good example can be seen in an advertisement in-themed Wardah Girls Day Out. The advertisement shows three teenagers who are visiting some places. While they are taking pictures, there are two men in the same age who are looking and paying attention to them. In the end, they interact with one another. Furthermore, the other Wardah advertisement shows a woman who wears Wardah cosmetics before she goes to work. In the office, while she is presenting her work through the internetconnected television screen, there is a male client who notices the woman and zooms her face on the screen. The last similar advertisement is from PIXY cosmetics. The advertisement mentions these interesting statements, "all eyes are on you" and "make your face smooth and delicate".

By guiding us to an image, advertisement not only sells products to us as women but also our personal relationships. It is showed us that we are feminine: how feminine women supposed to be, in which the attributes have relation with the men and family is from the use of these commodities. (Winship via Barker, 2008, p. 268). The cosmetics industry constructs the ideal beautiful woman from their view. Whiteface, thick eyebrows, flicks eyelashes, flushed lips, flushed cheeks and colored eyelids. Different cosmetic industries compete to make beauty products. The goal is to make every woman fulfill her "dream", that is to look beautiful by buying cosmetics products. The concept of the cosmetics is selling hope and dream. Not the reality (Tilaar, 1999, p. 173).

Advertisement becomes media to always shows woman beauty as a subject that is pushed to always obedient in the dominant discourse. Foucault constructs his mind to discourse issue, discipline and authority where discourse manages what can be said about people in certain social and cultural. Foucault explains, Particularly, the truth regime (What is seen as truth) from one discipline modernity brings power relation/knowledge, in which knowledge is a powerful form that gives effect to production subjectivity. (Foucault in Barker, 2008, p. 188). 


\subsection{Beauty Class and Beauty Vlog as Beauty Construction Space}

"It is my 4th time in joining Wardah beauty class. But I often see Youtube before this. I often see Suhay Salim video. She usually talks all the things about makeup, so it could be hours watching it. Here I am tutored directly by the committee, so I can directly ask questions every time I find something that I cannot understand. While on YouTube, if you still do not understand at the tutorial you can play the video again and again. I look around beauty vlogger video to know how to wear makeup properly and to know variations of makeup", Tisa said.

"It is the 6th time I join this event, hahaha. I incidentally became the winner of the best makeup. I just like to see a complete makeup kit so I can do experiment with makeup. I like seeing a video of SuhaySalim she explains about makeup products and the tutorials. I just want to know the update makeup hehe. So if there are certain events invitation like wedding invitation or just hang out with friends, I can apply the knowledge", Putri Said.

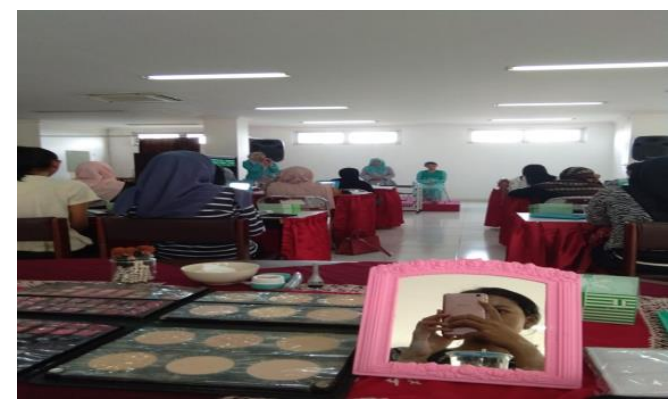

Fig. 1 Situation of Wardah Beauty Class (2017)

The last few years the phenomenon of beauty class and beauty vlogger becomes increasingly popular among young people. Beauty vlogs, as the point of the media production of makeup application, is to transfer skills to the millions of followers who will be reproducing (Banet, 2017, p. 277). Beauty vlogger usually starts with a review about beauty products to give a tutorial on how to apply beauty products with a variety of conditions. Suhay has been a trendsetter from video one makeup brand tutorial in Indonesia. Suhay Salim is a makeup artist. Suhay first uploading the video to YouTube on October 23, 2011. The video at that date has reached 115665 subscribers. Besides watching videos on Youtube beauty class, they also attend seminars held by Wardah beauty products.

Guy Debord states that the society of spectacle is communities whose almost every aspect of life is filled by various forms of spectacle, and they make it as a reference value and purpose of life (Debord in Hidayat, 2012, p. 66). Beauty vlogger Suhay Salim became one of their references in wearing makeup. The video is used as a reference in wearing makeup incorrect way. Makeup Variants and new makeup products are always followed. Beauty vlogger does a tutorial to tell the audience to decorate their faces with cosmetics by using some techniques and how to cover their faces which are considered less beautiful.

"Beauty vloggers are focused on the body; after all, the tutorials are meant to instruct viewer how to not only ornament their faces with makeup using specific mechanisms and techniques, but how to change their faces, how to hide parts of their faces, and how to embellish and or/ mask their face" (Banet, 2017, p. 273).

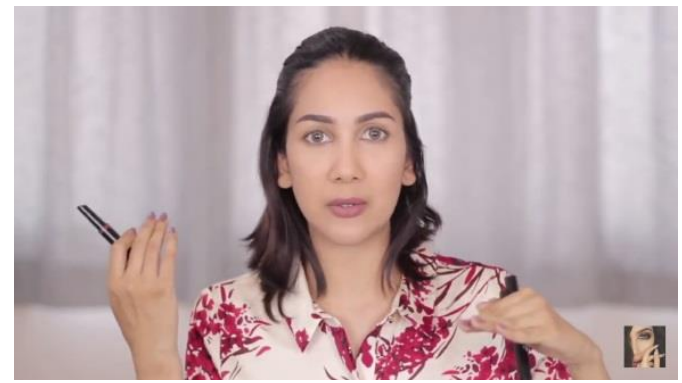

Fig. 2 Beauty Vlogger Suhay Salim ${ }^{1}$

\footnotetext{
${ }^{1}$ https;//youtu.be/IMC_s-uNG5A
} 
Beauty classes also become a standard reference on how to apply cosmetics to the face. One of the active cosmetic beauty class is from Wardah product. By paying IDR50,000 they can attend the class for two hours and get discounts on buying Wardah products separately. Wardah itself is one of cosmetics products that have segmentation to women of age 20-35 in the social middle class (Lestari, 2008, p. 3). The existence of Wardah beauty class let those who cannot access makeup kit/palette have the opportunity to try it. Said Tisa,

"The cost of beauty class is not so expensive. It's affordable for me. I just feel like by joining beauty class I can apply
and do experiment with the makeup palette that I never have. It is too expensive by the way to buy all the cosmetics
products, so by joining the beauty class, I can apply the makeup and I can get the knowledge too. Hahaha".

In the beauty classes, participants are given a tutorial to apply some cosmetics that have been prepared. From the technique of cleaning the face, contouring the face with foundation, applying powder, giving shading on the nose, coloring eyebrows, using eyeshadow, eyeliner, blush (as a blusher, and applying lipstick. At the end of the event, there will be time to determine the participant who looks perfect and beautiful in applying the makeup. Beauty and appearance are one of the beauty construction which is created. People make the construction to make a standard of beauty. A standard of beauty that is followed and applied in this life. The standard of beauty is created by strengthening the existence of beauty video and beauty classes.

"I have some products reviewed by Suhay like Maybelline mascara, NYX lipstick, Purbasari lipstick, and Wardah lipstick and eyeshadow. If the price is too expensive, usually I buy products that Suhay wear, at the last beauty I attended, I buy lipstick because there was a discount, hahaha", Putri Said.

"I also buy some cosmetic products after Wardah beauty class event. I buy cleaners, moisturizer, day and night creams, and eyeliner. I wear facial treatments to make my face looks clean. So it will be good looking" Tisa said

In the end, cosmetics become women's needs in order to fulfill their desire to be pretty. Women are conditioned to "need" cosmetic. In other words, the desire to be pretty and the need to dress up is not something given to women (Budiman, 2000, p. 47). At the end buying cosmetics becomes an activity that should be done. The act of consuming is like using or enjoying material and non-material things. According to Mary Douglas and Baron Isherwood via Rohana, consumption is a social process; it is a social need to relate to others through objects (Rohana 2003, p. 126). There are three reasons for consumption, material needs, psychological needs, and to meet ideal appearance.

The consumption way of people will affect their lifestyle. Lifestyle is understood as a way of life, including customs, views, and patterns in responding life events. Understanding the lifestyle will help us understand the reason some people do such a thing and whether they are doing meaningful behavior for themselves and others (Chaney, 2009, p. 40). The reason of people's behaviors and habits in consuming modern culture product is because those objects have a social life and thus affect humans to consume them (Lury in Blackshaw and Crawford, 2009, p. 40). Life Style is originated from the person's behavior which prioritize the consumption. This person's life has been dominated by the dominant standards. For the capitalists, beauty is a strategic thing that can be used as a commodity. So no wonder if this beauty myth continues to be reproduced. Beauty class as an extension of the way the industry continuously sells its products. By putting a discount label on products, consumers are not aware that they are being forced to buy the cosmetics. A beauty myth makes the consumption of beauty products continuously flow. A cosmetic is regarded as a thing that must be bought by women as by using makeup, their face are considered prettier. This has implications for the consumption of cosmetics they done. Buy cosmetics becomes a new routine in life. This makes them tend to be a beautiful woman. During the time of economic duress, women are more likely to spend money on cosmetics or beauty products as a sort of quick pick-me-up. The Lipstick Effect is the catchy name given to this phenomenon, women were more interested in purchasing beauty products than other items. (Cammorata, 2013, p. 126). 


\section{Conclusions}

Being beautiful is seen something valuable and should be owned. So it is not surprisingly that women are obsessed to have this beauty. They flocked to go to buy cosmetics, beauty watching beauty vlog, and attend beauty classes to meet the word "pretty". For the capitalists, it is a strategic area that can be used as a commodity. So do not be surprised if the beauty myths continue to be reproduced. Beauty class is an extension of the way the industry continues to sell its products. Applying cosmetics on the face is a form of an agreement for the dominant beauty discourse. Over the years human being have learned to construct their face. They began to put foundation, shading nose, coloring eyebrows, putting eyeliner, eyeshadow, lipstick, and blush on to meet a word "beautiful". Feminization makes them unsatisfied with their body. The face in the end becomes a sign of submission of women to the cultural construction and the male gaze. A beautification practice is determined by the standards of beauty defined by outsiders outside themselves. For instance, the cosmetics and beauty bloggers industry. A beauty class opens access for lower middle-class women to use a wide range of cosmetics palette and tools that are beyond what they can afford.

\section{References}

Banet, S. (2017). 'I'm beautiful way I am': Empowerment, beauty and aesthetic labour. London: Springer Nature (pp. 273-277).

Barker, C. (2014). The SAGE dictionary of cultural studies. Yogyakarta: Kanisius [In Bahasa Indonesia].

Blackshaw, T. \& Crawford, C. (2009). The SAGE dictionary of leisure studies. London: SAGE Publications Ltd.

Budiman, K. (2000). Feminis laki-laki dan wacana gender. [Feminist men and gender discourse]. Magelang: IndonesiaTera p. 47. [In Bahasa Indonesia].

Britton, A. M. (2012). The beauty industry's influence on women in society. Honors Theses. 86. Paper.

Cammorata, N. (2013). Words should know: The 201 word from science, politics, technology, and pop culture that will change your life this year. United States: Adams Media.

Chaney, D. (2009). Lifestyles: A comprehensive introduction. Yogyakarta: Jalasutra (p. 40).

Faruk. (2000). Women womeni lupus: Kumpulan esai-esai sosial. Magelang: Indonesia Tera.

Hidayat, M.A. (2012). Modernism. [Modernism]. Yogyakarta: Jalasutra.

Kemenperin.go.id. (2017). Susahnya kosmetik lokal berjaya di nusantara: Bahan baku impor 70 persen. [The difficulty of local cosmetics triumphed in the archipelago: Imported raw materials 70 percent]. Kemenperin. [In Bahasa Indonesia]. Retrieved from www.kemenperin.go.id/artikel/6018/SusahnyaKosmetik-Lokal-Berjaya-di-Nusantara:-Bahan-Baku-Impor-70-Persen

Kenny, E. \& Nichlos, E. G. (2017). Beauty around the World: A Cultural Encyclopedia. California: ABC-CLIO.

Marketeers.com. (2017). Menganalisa kosmetik perempuan milenial Indonesia. [Analyzing the cosmetics of Indonesian millennial women]. Merkerteers. [In Bahasa Indonesia]. Retrieved from http://marketeers.com/menganalisa-konsumsi-kosmetik-perempuan-milenial-indonesia/

Melliana S, A. (2006). Menjelajah tubuh: Perempuan dan mitos kecantikan. Yogyakarta: LKiS Yogyakarta, (p. 60).

Mulvey, L. (1975). Visual pleasure and narrative cinema. Screen 16(3), 6-18. 
Rondilla, J. L. (2017). Filipinos and the color complex: Ideal Asian beauty. In E. Glenn (Ed).EShades of Difference: Why Skin Color Matters. California : Standford Univesity Pers. (p. 64).

Tranggono, R. I. \& Latifah, F. (2007). Ilmu pengetahuan kosmetik. Jakarta: Gramedia (p.90).

Tilaar, M. (1999). Kecantikan Indonesia timur. Magelang: IndonesiaTera. (p. 173).

U.S. Food \& Drug Administration. (2017). Legal definition of "cosmetics". Retrieved from www.fda.gov/Cosmetics/Labeling/Regulation/ucm126438.htp\#top

Wolf, N. (2002). The beauty myth: How images of beauty are used against women. New York: Library of Congress Cataloging-in-Publication Data. (p. 10). 